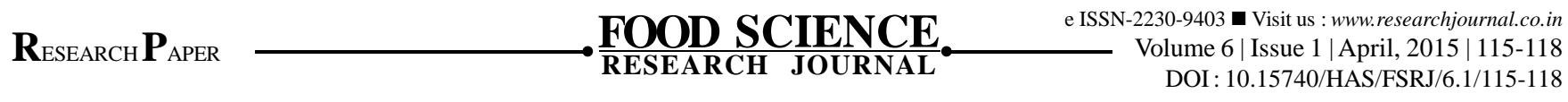

\title{
Consumers attitudes towards ready-to-eat-food
}

\author{
SHILPI JAIN
}

This Present study seeks to examine the consumer's attitudes towards ready to eat food. The study was conducted in the Raipur district of Chhattisgarh state. Primary data from 60 consumers were collected through personal interview method with the help of well-designed questionnaire. The study revealed that the consumers were more positively inclined towards "Ready-to-eat food" products and this was mainly due to the convenience factor and the change in the lifestyle of the people. The study suggests that the Ready-to-eat food product are very good example for time saving food. Long shelf life food product are very popular among teenage consumer of daily routine. $65 \%$ consumers were very happy is purchasing these food products. About $60 \%$ consumers agreed with hygienic condition of ready to eat food products.

Key Words : Consumer, Ready to eat food, Shelf life, Hygienic

How to cite this article : Jain, Shilpi (2015). Consumers attitudes towards ready-to-eat-food. Food Sci. Res. J., 6(1): 115-118. 